\title{
FACTORS OF INFLUENCE ON EVACUATION BEHAVIOUR: SURVEY RESULTS FROM THE RIVERINE FLOODPLAIN COMMUNITIES IN BANGLADESH
}

\author{
Md Sanaul Haque Mondal \\ Department of Social Relations, East West University, Jahurul Islam City, Aftabnagar, Dhaka, Bangladesh
}

Manuscript received: May 19, 2021

Revised version: August 2, 2021

\begin{abstract}
Mondal M.S.H., 2021. Factors of influence on evacuation behaviour: Survey results from the riverine floodplain communities in Bangladesh. Quaestiones Geographicae 40(3), Bogucki Wydawnictwo Naukowe, Poznań, pp. 85-93. 5 tables, 2 figs.

ABSTRACT: River floods are distinct because not all of them are destructive and typically affect the people who are living in riverine areas. Therefore, people often refuse to evacuate even when they face imminent danger. River floods are a recurrent phenomenon in Bangladesh. This research aims to analyse the flood evacuation behaviour of riverine people in Bangladesh. A total of 377 households were selected for the questionnaire survey and were interviewed from April 2019 to May 2019. Bivariate and multivariate statistics were employed to analyse riverine people's evacuation behaviour based on their socio-demographic and economic characteristics. This study found that although $82 \%$ of the households had received flood warning messages, only $40 \%$ had evacuated. Results from multivariate analysis suggested that the age of household heads, their education, whether they are disabled/chronically ill members, their income, the height of floodwater inside the house, and the type of warning messages they receive appear to be key determinants that influenced their decisions regarding evacuation. Elderly household heads had a lower likelihood to evacuate. The results showed a negative association between early warning messages and evacuation. Household with disabled/ chronically ill member(s) was associated with a higher likelihood of evacuation. Similarly, higher water depth in the home was associated with evacuation. These findings will be helpful for policymakers to enhance awareness of riverine households.
\end{abstract}

KEYWORDS: evacuation, riverine flood, early warning, Northern Bangladesh

Corresponding author: Md Sanaul Haque Mondal; mshaquem@gmail.com

\section{Introduction}

Bangladesh is one of the most flood-prone countries in the world. Riverine areas of the country are at high risk of flooding. These riverine areas are currently the home of around 19 million people (BBS 2015). From 2015 to 2020, the country experienced nine flooding events. The numbers of people affected by the 2020 floods were around 5.4 million, which showed a significant increase compared to the events in 2015 and 2016
(EM-DAT 2020). To ensure the safety of people in riverine areas, the Bangladesh government has been implementing different measures, including flood embankments, river training works, floodplain zoning, flood forecasting, and early warning system. Significant progress has been made to improve the early warning system of the country. However, the dissemination of the early warning messages to the end-users remains a challenge for the country (Chowdhury 2005, Rahman et al. 2013) resulting in an unsatisfactory response 
of end-users. Besides, behavioural factors also play a crucial role in the success of early warning messages (Rahman et al. 2013). Therefore, further studies are necessary to understand the factors that influence riverine households on evacuation.

Bangladesh experiences floods almost every year. However, the August 2017 flood was recorded as the worst flood in recent decades (Mondal et al. 2021). This flood affected around 1.75 million families and 147 people died (NDRCC 2017). Around 737,647 houses were damaged, and 605,034 hectares of croplands were destroyed. At least $11,359 \mathrm{~km}$ roads and $800 \mathrm{~km}$ embankments were damaged, and more than 900 bridges/culverts were destroyed (NDRCC 2017), leaving many areas inaccessible for emergency operation. The northern districts were severely affected by this flood.

Numerous studies from Bangladesh investigated early warning and evacuation decisions. The bulk of these studies are in the context of cyclones (Paul, Dutt 2010, Paul 2012, Ahsan et al. 2016). A handful of researches addresses flood early warning in Bangladesh (Chowdhury 2005, Shah et al. 2012, Rahman et al. 2013, Fakhruddin et al. 2015). Chowdhury (2005) proposed a fivestage framework for flood forecasting and early warning in Bangladesh. Shah et al. (2012) investigated farmers' response to flood warnings in the Brahmaputra floodplains. Rahman et al. (2013) collected opinions about the early warning dissemination system from the two flood-vulnerable communities of Dhobaura and Shibalaya sub-districts. Fakhruddin et al. (2015) studied the farmers' response to probabilistic forecasts in Kaijuri Union. Cumiskey et al. (2015) investigated the role of mobile phone services in improving the social performance of flash flood warnings. However, researches on the factors that influence evacuation response to flood warnings in Bangladesh are scarce. Moreover, no study has been conducted to explore the factors that influence households to evacuate in a safe place in the context of the 2017 flood. Therefore, understanding households' evacuation behaviour to recurrent riverine floods in Bangladesh is appropriate.

Keeping in view the current research gaps, this paper aims to assess the role of individual factors in the evacuation decisions of riverine flood-affected households in Bangladesh. This study will improve our understanding of riverine households' evacuation decisions to flood disasters, which is important to increase the resiliency of people in riverine areas of Bangladesh

\section{Responses to flood warning and evacuation}

This study used the existing approach (e.g. Paul, Dutt 2010, Paul 2012) on hazard warning and evacuation behaviour of individual households through the application of Bandura's Social Cognitive Theory (SCT). This theory provides a basis to understand the personal and environmental factors that shape individual behaviour in the context of an extreme natural hazard. Therefore, it presents a framework that illustrates the interactive dynamic relationships of personal and environmental factors, which determines an individual's behaviour (Wood, Bandura 1989). In this study, this framework is used to explain how

Table 1. Factors affecting evacuation decisions.

\begin{tabular}{|l|c|c|}
\hline \multicolumn{1}{|c|}{ Factor } & Decisions on evacuation & Examples of sources \\
\hline Socio-economic and demographic characteristics & & Adeola (2008) \\
\hline Age (older people) & + & Medina and Moraca (2016) \\
\hline Education (college level) & + & Paul (2012) \\
\hline Livestock ownership & + & Adeola (2008); Medina and Moraca (2016) \\
\hline $\begin{array}{l}\text { Dependent family member (e.g. having chil- } \\
\text { dren) }\end{array}$ & + & Mondal et al. (2021) \\
\hline Membership in NGOs & + & Lim et al. (2016) \\
\hline Income (poor households) & + & Medina and Moraca (2016) \\
\hline House ownership (own house) & + & Lim et al. (2016) \\
\hline Hazard related factors & + & (2016) \\
\hline Floodwater depth in house & + & Poraca \\
\hline Proximity to water source & & \\
\hline
\end{tabular}

NGOs - non-governmental organizations. 
households' characteristics, risk communication, and other relevant factors influenced the decision about evacuation in the context of riverine floods in Bangladesh.

Numerous studies have identified the factors that influence a household's evacuation decision including evacuation notice, the timing of the notice, household characteristics, social network, proximity to water sources (Dow, Cutter 1998, Wilmot, Bing 2004, Lindell, Perry 2012, Huang et al. 2015, Sadri et al. 2017, Alawadi et al. 2020). It is worth mentioning that these studies are mostly in the context of hurricanes and conducted mostly in developed countries. However, floods are recurrent in riverine areas and not all of them are destructive.

Studies revealed that flood evacuation behaviour is dependent on household socio-demographic characteristics and hazard-related factors (Adeola 2008, Shah et al. 2012, Lim et al. 2016, Medina, Moraca 2016) (Table 1). Adeola (2008) found that elder people are more likely to evacuate. Households with a college education are more likely to evacuate to their friends' or relatives' houses in non-flooded areas (Medina, Moraca 2016). Variables related to ownership of livestock had mixed effects on evacuation decisions (Paul 2012, Das 2019). Studies reported that the presence of dependent family members (e.g. children, chronically ill persons, disabled persons) encourages partial evacuation (Adeola 2008, Medina, Moraca 2016). Non-governmental organizations (NGOs) play an important role in emergency response such as relief distribution, evacuation and so on (Mondal et al. 2021). The level of income reflects the economic status of a household, which is considered an important predictor for evacuation (Medina, Moraca 2016). Shah et al. (2012) noted that a household's response to flood warnings is influenced by warning and receiver factors as well as economic factors. A household that owns a house is more likely to evacuate (Lim et al. 2016).

Hazard-related factors, such as the depth of floodwater in the house (Medina, Moraca 2016) and proximity to a water source also influence a household's decisions on evacuation (Lim et al. 2016). Chakma and Hokugo (2020) noted that people do not evacuate until observing the evidence of risk. Individuals also seek warning messages by observing river behaviour, rainfall trend, cloud colour or checking warning messages from alternative sources (Paul 2012). Other factors such as concern about looting, flood shelter centres being located in distant places, lack of space, no separate place for women, lack of latrines, and inadequate facilities discourage people to go to flood shelters (Mondal, Islam 2017, Saha, James 2017).

In this study, the word evacuation is used to mean 'evacuate in safer places before, during or after the occurrence of flood'. This does not necessarily mean that evacuating the threat area.

\section{Materials and methods}

\section{Materials}

The data for this study were collected using a questionnaire survey administered in the three flood-affected districts (Nilphamari, Rangpur, and Gaibandha) of the northern region of Bangladesh. The questionnaire survey was conducted from April 2019 to May 2019. Focus group discussions (FGD) with participating local leaders and residents were also used to collect relevant information. These interviews (FGD) allowed in-depth exploration of a variety of information,

Table 2. Key characteristic of the surveyed locations, year 2019.

\begin{tabular}{|c|c|c|c|}
\hline Category & Purbachhatnai & Gajaghanta & Belka \\
\hline Area $\left[\mathrm{km}^{2}\right]$ & 18 & 19 & 21 \\
\hline Total households & 3435 & 7929 & 7608 \\
\hline $\begin{array}{l}\text { Location along } \\
\text { the Teesta River }\end{array}$ & Upstream & Midstream & Downstream \\
\hline $\begin{array}{l}\text { Infrastructure } \\
\text { measures* }\end{array}$ & $\begin{array}{l}\text { Earthen and concrete em- } \\
\text { bankment, spurs were found } \\
\text { during the field visit, some } \\
\text { areas were exposed to river }\end{array}$ & $\begin{array}{l}\text { Earthen and concrete embankment, } \\
\text { embankment reconstruction was } \\
\text { going on during the field survey, } \\
\text { few areas are exposed to river due to } \\
\text { bank erosion }\end{array}$ & $\begin{array}{l}\text { Exposed to Teesta River, } \\
\text { no protection embank- } \\
\text { ment was found in the } \\
\text { field survey locations }\end{array}$ \\
\hline
\end{tabular}

* - based on personal observation. 
including, but not limited to, the characteristics of the flood, vulnerability and capacity, flood early warnings and evacuation, sheltering, and relevant issues that riverine people experienced during the 2017 flood.

The household-level questionnaire survey was administered in three unions, selecting one union from each district (Purbachhatnai from Nilphamari, Gajaghanta from Rangpur, and Belka from Gaibandha) (Fig. 1). These three unions are located on the right bank of the Teesta River in Bangladesh and have flat topography (Table 2). The principal flooding mechanism is the overflow of the riverbank. This overflow of the riverbank is accompanied by the peaks of floods along with widespread transportation and deposition (Zwoliński 1992). Floods are recurrent in these three unions. The questionnaire used was pretested and it recorded households' socio-economic information, flood characteristics, vulnerability and capacity of household, perception, household response, and other relevant information. An individual household was considered the primary sampling unit in this study. A complete list of all riverine households in the selected unions was not available. To select households from the riverine area, a systematic random sampling procedure was used. It was decided that the number of households to be interviewed from each union should be proportional to its size. The total number of households for these three unions was 18,972 (BBS 2013). A sample size of 377 was calculated using Cochran's Formula (Cochran 1977). The calculated sample sizes for each union were: 68 for Purbachhatnai, 158 for Gajaghanta and 151 for Belka. In each selected household, the male or female head of the household or the elderly was interviewed.
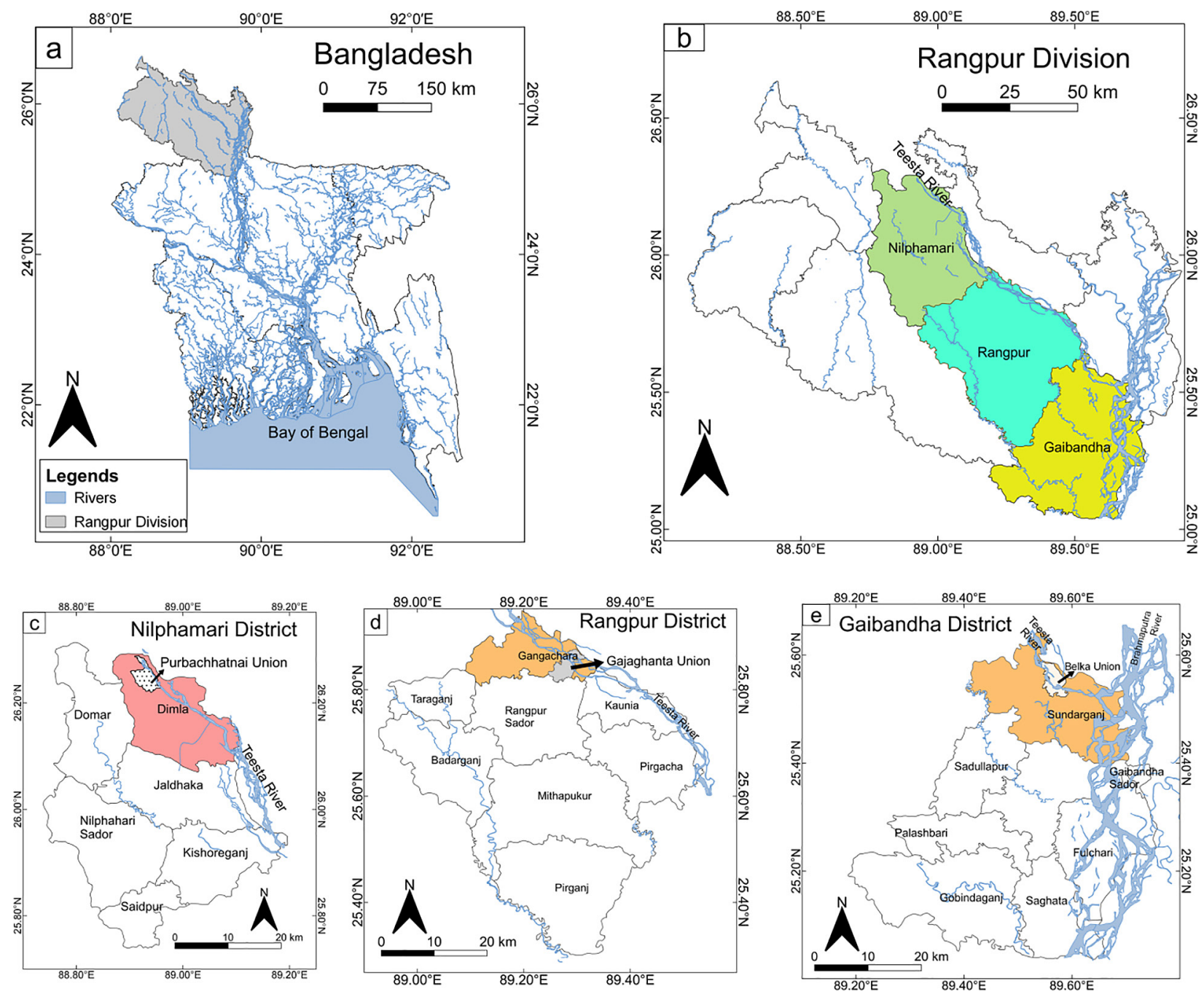

Fig. 1. Map of the study area. 


\section{Methods}

The descriptive analysis was performed using Pearson's $\chi^{2}$ test. A multivariate logistic regression model was used to determine the factors affecting a household's decision to evacuate. Because evacuation decision is in binary form (yes or no), logistic regression is an appropriate statistical technique.

\section{Selection of independent variables}

To identify factors of influence on evacuation decisions, a total of nine independent variables were selected based on the theoretical understanding, literature review and availability of data (Table 3). It is noted that all components of SCT are not entirely applicable for Bangladesh (Paul 2012). Therefore, the analysis of this study can be seen as a partial application of SCT.

\section{Results and discussion}

\section{Characteristics of households}

The average age of the household head was 48.9 years at the time of the questionnaire survey. Table 4 shows that only 20 of the 377 households were headed by a female member. About 33.4\% of the households reported a monthly income of $<6000$ BDT, whereas only about $23.9 \%$ earned
$>10,000$ BDT. The data also show that $48 \%$ of all households were agricultural landless (Table $4)$. Among the agricultural landholders, around $66 \%$ (128 out of 195) households owned between 0.21 acres and 1.00 acres. Agriculture was the primary occupation for $63.1 \%$ of all households, followed by wage labour $(22.8 \%)$. Concerning the level of education, around two-thirds of the households had studied beyond the primary level (Table 4). These socioeconomic characteristics of the households clearly indicate that riverine people are poor and have a lower level of education. These factors make riverine people more vulnerable to hydro-meteorological hazards, particularly floods, compared to people in other parts of the country.

\section{Early warning and evacuation behaviour}

The results of the questionnaire survey revealed that $82 \%$ of households received flood early warning in the 2017 flood. However, only $40 \%$ of households were evacuated from their residence in a safe place including flood shelter $(4.8 \%)$, school building $(4.8 \%)$, flood protection embankment $(21.0 \%)$, and neighbour's house $(18.0 \%)$ (Fig. 2). The highest percentage of households from Gajaghanta $\left(\chi^{2}=19.96, \mathrm{df}=2\right.$, $p \leq 0.010)$ were evacuated in a safe place. Around $44 \%$ of households received a warning message from a local leader or through a megaphone announcement. Mass media also plays an important

Table 3. Summary statistics of the selected variables (variables derived from questionnaire dataset, 2019).

\begin{tabular}{|c|c|c|c|c|}
\hline Category name & Variable & Variable description & Mean & SD \\
\hline \multirow[t]{6}{*}{ Socio-demographic } & Age & Age of household head (in years) & 48.93 & 14.15 \\
\hline & Education & Highest education within the households (continuous) & 7.31 & 3.90 \\
\hline & Disabled/ill & $\begin{array}{l}\text { Household has at least one disabled/chronically ill mem- } \\
\text { ber(s): yes }=1 \text {, otherwise }=0\end{array}$ & 0.37 & 0.48 \\
\hline & Income & $\begin{array}{l}\text { Monthly income of household >Tk. 10,001: yes = 1, other- } \\
\text { wise }=0\end{array}$ & 0.24 & 0.43 \\
\hline & Livestock & Household has livestock: yes $=1$, otherwise $=0$ & 0.60 & 0.49 \\
\hline & Affiliation & Household is affiliated with NGOs: yes $=1$, otherwise $=0$ & 0.19 & 0.40 \\
\hline \multirow[t]{2}{*}{$\begin{array}{l}\text { Hazard related } \\
\text { factors }\end{array}$} & Flooding experience & $\begin{array}{l}\text { Maximum height of floodwater inside the house in } 2017 \\
\text { flood (in feet) }\end{array}$ & 6.58 & 4.43 \\
\hline & Distance & $\begin{array}{l}\text { House is located within } 1000 \mathrm{~m} \text { from the riverbank: } \\
\text { yes }=1 \text {, otherwise }=0\end{array}$ & 0.85 & 0.36 \\
\hline $\begin{array}{l}\text { Early warning } \\
\text { message }\end{array}$ & Warning & $\begin{array}{l}\text { Household received last flood (in 2017) disaster warning: } \\
\text { yes }=1 \text {, otherwise }=0\end{array}$ & 0.82 & 0.39 \\
\hline \multirow[t]{2}{*}{ Regional variables } & Purbachhatnai & Household lived in Purbachhatnai: yes $=1$, otherwise $=0$ & 0.18 & 0.39 \\
\hline & Belka & Household lived in Belka: yes $=1$, otherwise $=0$ & 0.40 & 0.49 \\
\hline
\end{tabular}

Note: 1 US Dollar equal 84.25 BDT (Source: Bangladesh Bank, April 2019); BDT - Bangladeshi Taka; NGOs non-governmental organizations; SD - standard deviation. 
Table 4. Selected socioeconomic and demographic characteristics of the surveyed households, $n=377$, year 2019.

\begin{tabular}{|c|c|}
\hline Socio-demographic profile & $\begin{array}{l}\text { Percent- } \\
\text { age [\%] }\end{array}$ \\
\hline \multicolumn{2}{|l|}{ Age of household head (in years) } \\
\hline$<30$ & 7.7 \\
\hline $30-50$ & 45.9 \\
\hline$>50$ & 46.4 \\
\hline \multicolumn{2}{|l|}{ Sex of household head } \\
\hline Male & 94.7 \\
\hline Female & 5.3 \\
\hline \multicolumn{2}{|l|}{ Highest education within household } \\
\hline No formal education & 9.0 \\
\hline $1-5$ & 24.9 \\
\hline $6-10$ & 52.3 \\
\hline$>10$ & 13.8 \\
\hline \multicolumn{2}{|l|}{$\begin{array}{l}\text { Average income of the household } \\
\text { (in BDT per month) }\end{array}$} \\
\hline$<6000$ & 33.4 \\
\hline $6001-10,000$ & 42.7 \\
\hline$>10,001$ & 23.9 \\
\hline \multicolumn{2}{|l|}{ Occupation of household head } \\
\hline Agriculture & 63.1 \\
\hline Wage labour & 22.8 \\
\hline Business & 6.6 \\
\hline Service & 1.9 \\
\hline Others & 5.6 \\
\hline \multicolumn{2}{|l|}{ Construction material of the house } \\
\hline Thatched house & 6.4 \\
\hline Corrugated iron (CoI) & 76.9 \\
\hline Thatches with CoI sheet & 10.3 \\
\hline Semi wall & 6.4 \\
\hline \multicolumn{2}{|l|}{ Ownership of agricultural lands (in acres) } \\
\hline Without agricultural land & 48.0 \\
\hline $0.04-0.20$ acres & 7.4 \\
\hline $0.21-1$ acres & 34.0 \\
\hline$>1.01$ acres & 10.6 \\
\hline \multicolumn{2}{|l|}{ Ownership of land where the house is located } \\
\hline Own land & 68.3 \\
\hline Relative land & 22.7 \\
\hline Government (Khas) land & 2.5 \\
\hline Rented land & 6.4 \\
\hline
\end{tabular}

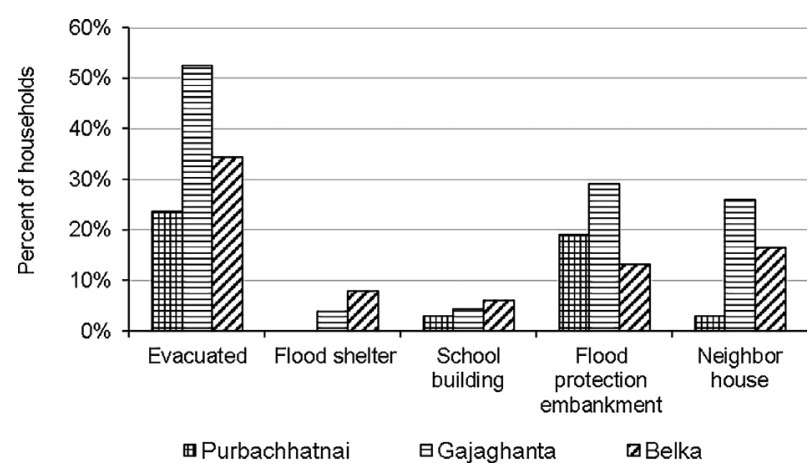

Fig. 2. Evacuation centres (multiple responses considered) reported by the households $(n=377$, year 2019). role and only $26 \%$ received warning information from television/radio/newspaper. Nearly $60 \%$ of the households received a warning message from their social connection (e.g. neighbours, relatives, friends). Around 18\% of households got warning information from the mosque. However, only three households received information from NGO officials.

\section{Factors associated with evacuation}

All the explanatory variables (Table 2) were included in the binary logistic regression model. Results of the binary logistic regression model of factors affecting evacuation behaviour to riverine flood disasters are presented in Table 5. Multicollinearity among the explanatory variables was checked using correlation analysis. The model is statistically significant, likelihood ratio $\chi^{2}=86.50, p \leq 0.001$. The Hosmer and Lemeshow $\chi^{2}$ test was non-significant for the model.

The study results showed that the age of the household head was negative and significantly related to evacuation. This implies that older household head is less likely to evacuate. This could be explained by the mobility issues as the age of the household head for the majority of the households with only two family members were $>45$ years. In the context of a hurricane in the USA, Alawadi et al. (2020) and Adeola (2008) reported that older household heads were less likely to evacuate. This could mean that disaster managers should design the evacuation plan in such a way that will better accommodate the elderly.

The results also showed that the probability of evacuation decreases with the increased level of education. This implies that educated households are less likely to evacuate. A review of the field data reveals that the majority of educated households with an education level of $>9$ grade had an income of $>10,000 \mathrm{BDT} /$ month, possess agricultural lands and mostly lives far away from the riverbank $(>1 \mathrm{~km})$ and modified their houses with strong materials to protect them from being flooded. This finding is different from other studies (Medina, Moraca 2016) that showed that educated households are more likely to evacuate. However, Lim et al. (2016) did not find any relation between education and evacuation.

Households with disabled/chronically ill members are more vulnerable to natural disasters 
than others (Islam et al. 2018). The findings of this study suggest that the likelihood of evacuation was higher among households with disabled/ill members. Studies reported that concerns about the well-being of vulnerable family members (e.g. chronically ill, disable) often lead to partial evacuation (Paul 2012). This finding necessitates the proper evacuation plan for the disabled and chronically ill members to evacuate in advance of a flood. These findings are consistent with Adeola (2008) that reported households with disabled people were more likely to evacuate than households without disabled people.

Table 5 shows that the evacuation rate was lower among the households that earned $>10,000$ $\mathrm{BDT} /$ month. This result is in the line with previous findings that showed that wealthier households are less likely to evacuate (Medina, Moraca 2016). This might be because higher-level income groups have adapted more strategies at their disposal to mitigate risk against flood.

The result shows that the evacuation rate was lower among the households who owned livestock compared to households without having livestock, but this difference is not statistically significant. This may be because shelters are not equipped to keep livestock which demotivates households to evacuate. Therefore, instead of taking shelter in a safer place with their livestock, they prefer to stay at home with their livestock. Studies noted that cattle owners from the coastal

Table 5. Logistic regression results for factors associated with evacuation behaviour $(1$ = evacuated; $0=$ not evacuated, $\mathrm{n}=377$, year 2019).

\begin{tabular}{|l|c|c|c|}
\hline \multicolumn{1}{|c|}{ Variables } & B & SE & $\operatorname{Exp}(\mathrm{B})$ \\
\hline Age & $-0.034^{* * *}$ & 0.009 & 0.967 \\
\hline Education & $-0.084^{*}$ & 0.033 & 0.919 \\
\hline Disabled/ill & $0.774^{* *}$ & 0.267 & 2.168 \\
\hline Income & $-0.753^{*}$ & 0.309 & 0.471 \\
\hline Livestock & -0.213 & 0.251 & 0.808 \\
\hline Affiliation & -0.061 & 0.314 & 0.941 \\
\hline Flooding experience & $0.074^{*}$ & 0.035 & 1.077 \\
\hline Distance & 0.178 & 0.342 & 1.194 \\
\hline Warning & $-1.270^{* * *}$ & 0.326 & 0.281 \\
\hline Purbachhatnai & $-1.400^{* * *}$ & 0.363 & 0.247 \\
\hline Belka & $-1.548^{* * *}$ & 0.345 & 0.213 \\
\hline Constant & $3.050^{* * *}$ & 0.772 & 21.119 \\
\hline
\end{tabular}

Note: ***, **, * imply significance at $0.1 \%, 1 \%$, and $5 \%$ levels, respectively; LR X2 (11) = 86.497; Log likelihood: 421.115; Nagelkerke R2: 277; SE - standard error. region of Bangladesh are less likely to evacuate to cyclone shelters (Saha, James 2017).

Affiliation with NGOs did not appear as a significant predictor of evacuation behaviour. This may be because NGOs are mainly supporting livelihood enhancement overlooking the longterm resilience of riverine people. Besides, floods are recurrent in the study areas. Thus, the evacuation behaviour was not significantly different across affiliated NGO groups.

The height of floodwater inside the room was positively related to evacuation. This implies that riverine people still consider the 'wait and see' approach for evacuation. People refuse to evacuate as long as the floodwater does not rise within their homestead. Another reason could be related to their experience with the previous flood (Ourn, Suntornvongsagul 2015), which leads them to act upon seeing the characteristics of the flood. In the case of risk management, it is thus essential to raise the awareness of people to act upon getting the evacuation notices. Besides, the warning messages should be disseminated in an easily understandable way. This result is in the line with previous findings that showed that households who experienced deeper inundation were more likely to evacuate than those who experienced shallow flooding depth (Medina, Moraca 2016).

The location of the house from the riverbank did not influence evacuation behaviour. This is because, irrespective of their house location, a majority of the surveyed households faced inundation of their houses in 2017 and thus no significant differences were observed. Some scholarly evidence showed that proximity to water positively influenced hurricane evacuation (Wilmot, Bing 2004).

Surprisingly, the results revealed a negative relationship between evacuation and warning messages. This may be because more than half of the households received warning messages $<6 \mathrm{~h}$, which discouraged households to evacuate in a safe place. This finding is consistent with earlier research findings of Shah et al. (2012). Results of the FGD, (Purbachhatnai) revealed that the early warning system in the study area is very poor. In most cases, they received information about the increase or decrease of the water level of the Teesta River. But they do not know how much the water level might increase in the coming days. People usually use environmental cues (e.g. cloud 
colour, wind direction, exceptional behaviour of animals, observing celestial bodies, and river watercolour) to guess river flood (Mondal 2012). However, people become helpless when there is an onrush of water from the upstream due to the opening of barrage gates (Mondal et al. 2020).

On the other hand, the probability of evacuation was significantly higher in Gajaghanta than in the other two survey locations.

\section{Conclusions}

This study examined households' evacuation behaviour to the 2017 flood disaster in the northern region of Bangladesh. This study identified several factors that determine households' evacuation behaviour to a river flood. These factors include the age of the household head $(p<0.001)$, received early warning messages $(p<0.001)$, disable/chronically ill member $(p=0.004)$, education $(p=0.011)$, income $(p=0.015)$, and the height of floodwater inside the room $(p=0.036)$. Also, the study identified regional variations in the evacuation behaviour of the riverine people. To make riverine households more aware of the floods irrespective of age, education and income sources, the disaster managers must educate them about the benefits of taking shelter in a safe place before danger. This can be done by arranging a regular meeting with flood-affected households. The provision of livestock shade adjacent to the flood shelter will also increase the evacuation rate. The findings also showed that lack of information about the severity of flood (level of water rise of the river) inhibited riverine people to evacuate. It is, therefore, necessary to improve the flood early warning system so that it incorporates behavioural aspects of human responses to warnings.

The decision to evacuate or not is very complex in Bangladesh, especially for the river flood. The findings of this study are based on the analysis of evacuation behaviour for a specific flooding event in the riverine areas of Bangladesh. Evacuation behaviour is different from flood to flood and thus, the findings cannot be generalised for the whole riverine areas of Bangladesh or other parts of the world. Also, the use of a binary logistic regression model offers only two outcomes (evacuated vs. not evacuated) and does not offer insights on whether all or partial members of the family were evacuated. Studies similar to this can be conducted in other riverine areas to validate the findings of this study.

\section{Acknowledgements}

The author is thankful to the respondents and local stakeholders for their support during the entire period of the field survey. Thanks to anonymous reviewers for their insightful comments. The author is grateful to the JICA Innovative Asia Programme.

\section{References}

Adeola F.O., 2008. Katrina cataclysm: Does duration of residency and prior experience affect impacts, evacuation, and adaptation behavior among survivors? Environment and Behavior 41(4): 459-489. DOI 10.1177/0013916508316651.

Ahsan M.N., Takeuchi K., Vink K., Warner J., 2016. Factors affecting the evacuation decisions of coastal households during Cyclone Aila in Bangladesh. Environmental Hazards 15(1): 16-42. DOI 10.1080/17477891.2015.1114912.

Alawadi R., Murray-Tuite P., Marasco D., Ukkusuri S., Ge Y., 2020. Determinants of full and partial household evacuation decision making in hurricane Matthew. Transportation Research Part D: Transport and Environment 83: 102313. DOI 10.1016/j.trd.2020.102313.

BBS [Bangladesh Bureau of Statistics], 2013. Population \& housing census - 2011: Community Report: Gaibandhal Nilphamari/Rangpur. Bangladesh Bureau of Statistics, Dhaka, Bangladesh.

BBS [Bangladesh Bureau of Statistics], 2015. Population density and vulnerability: A challenge for sustainable development of Bangladesh. Bangladesh Bureau of Statistics, Dhaka, Bangladesh.

Chakma S., Hokugo A., 2020. Evacuation behavior: Why do some people never evacuate to a cyclone shelter during an emergency? A case study of coastal Bangladesh. Journal of Disaster Research 15(4): 481-489. DOI 10.20965/ jdr.2020.p0481.

Chowdhury M.R., 2005. Consensus seasonal Flood Forecasts and Warning Response System (FFWRS): an alternate for nonstructural flood management in Bangladesh. Environmental Management 35(6): 716-725. DOI 10.1007/ s00267-004-0010-4.

Cochran W.G., 1977. Sampling techniques. John Wiley \& Sons, New York.

Cumiskey L., Werner M., Meijer K., Fakhruddin S.H.M., Hassan A., 2015. Improving the social performance of flash flood early warnings using mobile services. International Journal of Disaster Resilience in the Built Environment 6(1): 57-72. DOI 10.1108/IJDRBE-08-2014-0062.

Das, S., 2019. Evaluating climate change adaptation through evacuation decisions: a case study of cyclone management in India. Climatic Change 152(2): 291-305. DOI 10.1007/s10584-018-2292-1.

Dow K., Cutter S.L., 1998. Crying wolf: repeat responses to hurricane evacuation orders. Coastal Management 26(4): 237-252. 
EM-DAT, 2020. EM-DAT [online]. The international disasters database- Université catholique de Louvain (UCL) - CRED, D. Guha-Sapir. Université catholique de Louvain (UCL) CRED, D. Guha-Sapir. Available from: https://www.emdat.be/ (accessed 14 January 2020).

Fakhruddin S.H.M., Kawasaki A., Babel M.S., 2015. Community responses to flood early warning system: Case study in Kaijuri Union, Bangladesh. International Journal of Disaster Risk Reduction 14: 323-331. DOI 10.1016/j. ijdrr.2015.08.004.

Huang S.-K., Lindell M.K., Prater C.S., 2015. Who leaves and who stays? A review and statistical meta-analysis of Hurricane evacuation studies. Environment and Behavior 48(8): 991-1029. DOI 10.1177/0013916515578485.

Islam S., Mondal S.H., Kabir I.M.H.M. 2018. Coping with natural disasters: a cross-sectional study with people with disabilities in the coastal zone of Bangladesh. Journal of the Geographical Institute" Jovan Cvijic", SASA 68(1): 6783. DOI 10.2298/IJGI1801067I.

Lim M.B.B., Lim H.R., Piantanakulchai M., Uy F.A. 2016. A household-level flood evacuation decision model in Quezon City, Philippines. Natural Hazards 80(3): 1539-1561. DOI 10.1007/s11069-015-2038-6.

Lindell M.K., Perry R.W., 2012. The protective action decision model: theoretical modifications and additional evidence. Risk Analysis 32(4): 616-632. DOI 10.1111/j.15396924.2011.01647.x.

Medina, M.A.P., Moraca J.M., 2016. Should I stay or should I go? Determinants of evacuation upon flood warning among households in a flood prone area in Bukidnon, Philippines. International Letters of Natural Sciences 50: 70-75. DOI 10.18052/www.scipress.com/ILNS.50.70.

Mondal M.S.H., 2012. Disaster management through indigenous wisdom: voice from the people of Erendabari Char. Journal of South Asian Disaster Studies, 5(1\&2): 27-35.

Mondal M.S.H., Islam M.S., 2017. Chronological trends in maximum and minimum water flows of the Teesta River, Bangladesh, and its implications. JÀMBÁ: Journal of Disaster Risk Studies 9(1): 1-11. DOI 10.4102/jamba. v9i1.373.

Mondal M.S.H., Murayama T., Nishikizawa S., 2020. Assessing the flood risk of riverine households: a case study from the right bank of the Teesta River, Bangladesh. International Journal of Disaster Risk Reduction 51L 101758. DOI 10.1016/j.ijdrr.2020.101758.

Mondal M.S.H., Murayama T., Nishikizawa S., 2021. Determinants of household-level coping strategies and recov- eries from riverine flood disasters: empirical evidence from the right bank of Teesta River, Bangladesh. Climate 9(1): 4, 1-18. DOI 10.3390/cli9010004.

NDRCC [The National Disaster Response Coordination Centre], 2017. Daily disaster situation: 12 September 2017. The National Disaster Response Coordination Centre (NDRCC), Department of Disaster Management, Dhaka.

Ourn V., Suntornvongsagul K., 2015. Copying mechanisms in repeated floods areas: a case study in Ba Baong commune in Prey Veng province, Cambodia. Environment and Natural Resources Journal 13(2): 33-43.

Paul B.K., 2012. Factors affecting evacuation behavior: the case of 2007 Cyclone Sidr, Bangladesh. The Professional Geographer 64(3): 401-414. DOI 10.1080/00330124.2011.609780.

Paul B.K., Dutt S., 2010. Hazard warnings and responses to evacuation orders: the case of Bangladesh's Cyclone Sidr. Geographical Review 100(3): 336-355. DOI 10.1111/j.19310846.2010.00040.x.

Rahman M.M., Goel N.K., Arya D.S., 2013. Study of early flood warning dissemination system in Bangladesh. Journal of Flood Risk Management 6(4): 290-301. DOI 10.1111/ jfr3.12012.

Sadri A.M., Ukkusuri S., Hugh G., 2017. The role of social networks and information sources on hurricane evacuation decision making. Natural Hazards Review 18(3): 4017005. DOI 10.1061/(ASCE)NH.1527-6996.0000244.

Saha S.K., James H., 2017. Reasons for non-compliance with cyclone evacuation orders in Bangladesh. International Journal of Disaster Risk Reduction 21: 196-204. DOI 10.1016/j.ijdrr.2016.12.009.

Shah M.A.R., Douven W., Werner M., Leentvaar J., 2012. Flood warning responses of farmer households: a case study in Uria Union in the Brahmaputra flood plain, Bangladesh. Journal of Flood Risk Management 5(3): 258269. DOI 10.1111/j.1753-318X.2012.01147.x

Wilmot Ch.G., Bing, M., 2004. Comparison of alternative trip generation models for Hurricane evacuation. Natural Hazards Review 5(4): 170-178. DOI 10.1061/(ASCE)15276988(2004)5:4(170).

Wood R., Bandura A., 1989. Impact of conceptions of ability on self-regulatory mechanisms and complex decision making. Journal of Personality and Social Psychology, 56(3): 407-415. DOI 10.1037/0022-3514.56.3.407,

Zwoliński Z., 1992. Sedimentology and geomorphology of overbank flows on meandering river floodplains. Geomorphology 4(6): 367-379. DOI 10.1016/0169-555X(92)90032-J. 